\title{
The Use of Lethal Force by Canadian Police Officers: Assessing the Influence of Female Police Officers and Minority Threat Explanations on Police Shootings Across Large Cities
}

\author{
Jason T. Carmichael
}

Stephanie L. Kent

Cleveland State University, s.l.kent59@csuohio.edu

Follow this and additional works at: https://engagedscholarship.csuohio.edu/clcas_facpub

How does access to this work benefit you? Let us know!

\section{Publisher's Statement}

The final publication is available at Springer via: https://link.springer.com/article/10.1007/ s12103-014-9283-1

\section{Recommended Citation}

Carmichael, Jason T. and Kent, Stephanie L., "The Use of Lethal Force by Canadian Police Officers: Assessing the Influence of Female Police Officers and Minority Threat Explanations on Police Shootings Across Large Cities" (2015). Criminology, Anthropology, \& Sociology Faculty Publications. 4.

https://engagedscholarship.csuohio.edu/clcas_facpub/4

This Article is brought to you for free and open access by the Criminology, Anthropology, \& Sociology Department at EngagedScholarship@CSU. It has been accepted for inclusion in Criminology, Anthropology, \& Sociology Faculty Publications by an authorized administrator of EngagedScholarship@CSU. For more information, please contact library.es@csuohio.edu. 


\title{
The Use of Lethal Force by Canadian Police Officers: Assessing the Influence of Female Police Officers and Minority Threat Explanations on Police Shootings Across Large Cities
}

\author{
Jason T. Carmichael • Stephanie L. Kent
}

\begin{abstract}
This study examines the applicability of several theoretically derived accounts used to explain the variations in police killings across 39 of Canada's largest cities over a 15year period. Pooled time-series negative binomial regression results are consistent with the ethnic threat hypothesis by indicating that lethal police action is associated with the size of the ethnic minority population in each city. Political accounts are supported as non-linear specifications suggest that once ethnic minorities reach a numerical majority in our sample of cities there is a decline in police killings. Findings also support expectations that greater female representation within policing will reduce the use of lethal force by changing the overall culture of the department. Theoretical implications of our findings are discussed.
\end{abstract}

\section{Introduction}

A unifying task of all police agencies is to maintain social order, and it is clear that violence is one means of accomplishing this task (Manning 1980). Police departments in large cities are almost always the first government agency employed to handle threats to internal stability. The police in modern society therefore find themselves acting as "the cutting edge of the state's knife" (Chevigny 1995; pg. 10). Effective law enforcement agencies are crucial in even the most progressive societies as police officers are the most proficient and least conspicuous specialists in the day to day use of coercion that is required to preserve domestic 
order (Silver 1967; Bittner 1990). Police use of force, especially when it is considered excessive or unjustified, can weaken police-citizen relations and overall social cohesion. Tensions between the police and ordinary citizens regularly erupt over the use of lethal force often because citizens of western societies are now increasingly reluctant to endorse the use of physical force as a mechanism of social control (Alpert \& Dunham 2004) and because the use of lethal force disproportionately involves minority victims (Smith \& Holmes 2014; Holmes 2000; Fitzgerald \& Carrington 2011; Pedicelli 1998). Such events are well publicized and often lead to community allegations of police discrimination.

Unlike the United States, where a sizable body of literature on police use of lethal force exists, few studies have attempted to examine these events in Canada (for exceptions see Parent 2011; Pedicelli 1998). This is likely because Canada has no available data source that tracks the frequency of police shootings across all jurisdictions in the country. Our study overcomes this data limitation by using a newspaper archival approach that allows us to capture police killings across the country over 15 years. Data from this archival collection will help to improve our understanding of police killings in Canada because we can use it to assess the influence that several theoretically derived factors have on this outcome.

Some of the most important explanations for police coercive behavior stem from conflict perspectives which suggest that police officers are more likely to use deadly force against members of minority groups or those groups who threaten the status quo (Smith \& Holmes 2014; Liska \& Yu 1992). Accordingly, if police officers make decisions based on perceived threats posed by minority presence, then their likelihood of using deadly force should be greater in places where ethnic stratification exist. While research based on sampled in the United States supports this assertion (Jacobs \& Britt 1979), no study has attempted to test the applicability of such claims in the Canadian context. Because conflict theory should be useful in explaining how police retain the volatile balance of power in unequal cities, we consider this theory in addition to other perspectives on police violence by employing econometric analyses to measure variation in these rare but lethal events across the largest municipalities in Canada.

\section{Background on Police Violence Research}

Research on police violence has typically focused on differences among individuals, situations, departmental differences, as well as variations in the community in which particular police organizations are embedded. Individual-level analyses focus on police violence as a product of individual officer characteristics such as an officer's age, race, gender or level of education. Most indicate that such attributes are unimportant once situational or other external factors are held constant (for a review see Adams 2004). Situational-level studies conducted in the U.S. consider factors that surround policecitizen encounters (Klinger 1997; Blumberg 1993) and typically report that police are more likely to use force against hostile citizens (Klinger 1997) and racial minorities (Friedrich 1979). Canadian scholars have come to similar conclusions showing that members of a visible minority group are far more likely to be stopped, searched and arrested than non-minorities (Wortley \& Owusu-Bempah 2011; Wortley \& Tanner 2003; Wortley 1999). Studies of policing in Canada have also provided evidence that ethnic minorities are subject to higher rates of police use of lethal force (Pedicelli 1998).

Other assessments of the variation in police killings consider macro rather than micro (individual)-level factors. Because police shootings vary widely from one department to 
another, some scholarship on police use of force has assessed whether or not the internal dynamic of municipal police departments themselves or structural conditions within the cities they police influence the use of lethal force (e.g. Smith \& Holmes 2014; Holmes 2000; Jacobs \& O'Brien 1998). Seminal work by David Jacobs and Robert O'Brien (1998) examined differences in police use of deadly force across a large number of cities and found that those with the most African Americans had the most police killings even after controlling for the level of violent crime and other structural factors. They argue that these findings illustrate that social control agencies exist to serve the interests of the powerful in society and that these privileged groups will use law enforcement agents to maintain control over the "dangerous classes" (pg. 838) who threaten their advantaged position within society. While their argument may offer a compelling explanation for variations of police killings in the U.S., the extant literature does not consider the applicability of such accounts outside of the U.S. context. The goal of the present study is to rectify this gap in the literature by assessing whether or not variations in police killings are determined in part by differences in the contextual factors across major cities in Canada.

\section{Theorizing the Use of Lethal Force by Police Officers}

Previous research suggests that there are multiple explanations for police use of deadly force against citizens. The first suggests that attempts to increase diversity within a police department should reduce the use of force by officers. A second theoretical account assumes that killings by police are affected by community differences in racial stratification. Finally, a number of scholars have argued that adverse structural conditions like high levels of poverty can influence police action in such a way that produces greater reliance on force. This study will test each of these perspectives using data on police shootings in large Canadian cities between 1996 and 2010. Before we discuss our data and summarize our findings, we will first outline our theoretical expectations in more detail.

\section{Departmental Characteristics-Female Police Officers}

As discussed above, the extent literature on police use of force has examined how internal dynamics within a department may influence the use of violent tactics. Research has shown, for example, that increasing diversity by hiring more ethnic or racial minorities does not appear to produce any meaningful reduction in the use of force within a given jurisdiction (see Adams 2004). There is some evidence, however, that hiring female officers may reduce the use of force by officers. A number of scholars have argued that differences in policing styles between men and women originate from differential socialization as well as biological differences (see RabeHemp 2008 for a detailed account). Gilligan (1982) argues that gendered patterns of socialization give women a unique feminine world view in which empathy and caring play a central role. Empirical evidence has offered consistent supported for such assertions showing that females espouse more altruistic behavior (Piliavin \& Chang 1990) more empathy (Gilligan 1982), and are less likely to use physical aggression than males (Fletcher 1999). These unique qualities may allow women to bring a different set of skills and talents to policing that may reduce the use or abuse of force. 
Given these gender differences, Skolnick and Fyfe (1993), argued that increasing the number of women in policing should reduce the illegitimate use of force not only because female officers are less likely to employ physical force but because they may be able to change the traditionally male-dominated, aggressive subculture that has long dominated the profession to one that is more kind, respectful and gentle (see Kappeler et al. 1994). While the empirical support for such a claim has been somewhat mixed, a growing body of policing scholarship offers substantial evidence that female officers perform their duties in a less violent manner than male officers. Recent reports, for instance, suggest that female officers are 2-3 times less likely to be the subject of citizen complaints and nearly 10 times less likely to have allegations of excessive force directed at them (Lonsway et al. 2002). Other studies suggest that policewomen are far less inclined to use force against suspects (Schuck \& Rabe-Hemp 2005; Lersch \& Mieczkowski 2005), they are much less likely to use their weapon when confronted by a suspect (Alpert \& Dunham 2004; Hoffmann \& Hickey 2005) and in simulated "shoot/don't shoot" training exercises they tend to stay holstered longer that their male counterparts (Doerner 1991). Critics argue that much of the research pointing to gender differences in policing fails to account for the possibility that systematic gender-based differences in assignments exist which could produce gender differences in the need to use force (e.g. Belknap 1996). Nonetheless, the preponderance of the research appears to suggest that increasing the number of women in policing will reduce the incidents of police violence.

Guided at least in part by this research, policymakers in the U.S. and to a somewhat greater extent, Canada, have expanded female representation within police departments partly in the hopes that such policies would reduce the use of force. Since the 1980s, female officers comprise an increasing proportion of patrol officers in both the U.S. and Canada. Today policewomen account for roughly $16 \%$ of all officers in the U.S. (Sourcebook of Criminal Justice Statistics 2003) and over $20 \%$ in Canada (Statistics Canada 2013). Yet despite such substantial growth in the representation of women in policing, we know little about the effect this change has had on the overall levels of force employed by officers. The scholarship outlined above suggests that female officers are less inclined to employ force, but no study that we know of has assessed Skolnick and Fyfe's (1993) additional claim that employing more female officers could change the culture within the entire department in ways that make it less aggressive. Rabe-Hemp (2008) conducted in-depth interviews of female officers and reported that "the evolution of the police culture in their respective departments included more "enlightened' men" (p.263). She concluded that the police subculture literature should therefore be reconsidered to account for a greater variation in values apparent in the modern police culture. While this research did not specifically examine use of force, it suggests that the incorporation of women into police departments has changed the traditional subculture of departments. To test whether this claim extends to shifts in the department's overall use of force requires the type of aggregate analytical strategy we employ here. If Skolnick and Fyfe's (1993) assertions are correct, we should expect to see fewer police killings in jurisdiction with more female police officers.

\section{Minority Threat Hypotheses}

Foundational work in the sociology of law provides a basic explanation for the role of coercion in the maintenance of social order. Sociologists have argued that social control 
agents favor the privileged within society (Dahrendorf 1959; Turk 1969). Black (1976), for example, argues that government agents such as the police apply the law against some groups more than others based on differences in class, race, and the relative social distance between parties in police-citizen interactions. Conflict theorists extend this claim by suggesting that the public, in addition to officers themselves, has a role in the application of social control. They argue that dominant groups in society view a large racial or ethnic minority population as a criminal threat (Blumer 1958; Blalock 1967) and that majority group members will use their disproportional influence over the criminal law and criminal justice policies to support policies and practices that will control groups perceived as threatening to the social order and the status quo that benefits them (Quinney 1977; Collins 1975). The fear is that without a substantial threat of coercion, minority group members may use violence to redistribute societal resources more equitably (Blau \& Blau 1982).

Scholarship conducted in the U.S. has offered rather considerable support for the claim that the presence of a large racial or ethnic underclass will lead to increases in coercive measures. Previous studies found that cities with larger African-American populations had more police killings (Sorenson, Marquart \& Brock 1993) and more police killings of African Americans (Jacobs and O'Brien 1998). Other studies found a link between minority threat and other forms of social control including police force size (Carmichael \& Kent 2014; Kent \& Carmichael 2014) expenditures on police (Nalla, Lynch \& Leiber 1997; Jackson 1989) or prisons and jails (Jacobs \& Helms 1999), higher arrest rates (Liska et al. 1984), greater use of jails (Carmichael 2005); longer sentence of incarceration (Carmichael \& Burgos 2012; Carmichael 2010) and more death sentences (Jacobs \& Carmichael 2004). Despite such substantial support for the threat hypothesis in the U.S., few studies have assessed whether or not threat hypotheses are applicable in Canada and, in particular, if and how minority presence may influence criminal justice policies and practices in that country.

The limited Canadian criminal justice scholarship that can speak to this possibility has offered rather compelling evidence that ethnic discrimination exists in the Canadian legal system. It has been well demonstrated, for instance, that Aboriginals and visible minorities are over-represented at nearly every stage of the criminal justice system (Fitzgerald \& Carrington 2011; Wortley 1999). These studies have shown that ethnic minorities are more likely to be stopped and searched by law enforcement (Fitzgerald \& Carrington 2011; Wortley \& OwusuBempah 2011) and such heightened police attention has produced higher rates of minority involvement in other stages in the criminal justice system including more arrests (Wortley 1999), and higher risk of incarceration for their crimes (Roberts \& Doob 1997).

Only a few studies have examined police use of deadly force in Canada to see if these events are more likely to involve minorities. The most important of these was conducted by Gabriella Pedicelli (1998) who used newspaper coverage in two Canadian cities (Montreal and Toronto) to study incidents of police killings between 1994 and 1997. She found that about half of the police killings in Montreal and Toronto during that period involved Black residents even though this group accounts for less than $5 \%$ of either cities' population. Pedicelli reported that officers often justified the use of lethal force against ethnic minorities by claiming that these groups were prone to 'criminality' and 'violence'. 
Given such evidence, it seems at least plausible that ethnic threat theory could be applicable to the Canadian context and may partly explain the incidence of deadly force. If ethnic threat theories are relevant in Canada then we should expect to see more police killings in Canadian cities with a large visible minority or Aboriginal population. Because the potential threat or fear of ethnic minorities may be largely related to immigrant status (recall that nearly $70 \%$ of recent immigrants are visible minorities) a substantial presence of this group may produce more police killings. According to the theory, officers may be more likely to respond with violence in places with a large, potentially threatening minority population, perhaps because the racial/ethnic majority of the public (in Canada, the non-minority or non-Aboriginal population) either supports enhanced social control in these areas, or does not protest police use of force. This possibility of this relationship is strengthened by Todd Gordon's (Gordon 2006 account of policing in Canada. He writes ethnic minorities "are seen by state authorities as a problem race.", and that "...in the minds of police, the targeting of people of colour on the streets and in public spaces is the targeting of immigrants." (pg. 126).

On the other hand, visible minorities and immigrants make up the majority of the population in some large Canadian cities so residents of these communities may be less likely to perceive minorities as a threat and so they should be less likely to demand or support violent policing tactics that disproportionately target minorities. Once minorities approach a numerical majority in a city, they may be able to mobilize in ways that force political elites to make policy changes that make the use of lethal force by the police less likely (Jackson 1989; Turk 1969). We test this assumption by assessing the possibility of a non-linear relationship between minority presence and police killings such that these events should increase until some threshold in the minority population is reached, after which point police killings should decline.

\section{Reactive Explanations}

Legalistic explanations assert that the level of police violence in a geographic area is a function of the level of violent crime. Qualitative research on police behavior suggests that the use of lethal force by the police is most likely in areas where the police encounter and must react to violent populations (Rubenstein 1973). Other early studies on the situations surrounding police use of force found that the majority of police killings involved use or threatened use of weapons by those who were killed (Binder \& Fridell 1984). Most of the previous macro research conducted in the U.S. found that the level of violence in the community is a strong predictor of the rate of police killings (Fyfe 1980; Jacobs \& Britt 1979; MacDonald et al. 2001; Sorenson et al. 1993; Jacobs \& O'Brien 1998). Because the murder rate is the most accurately measured of all violent crimes, and based on the evidence provided by the above studies, we should expect to see more police killings in Canadian cities with high murder rates.

\section{Additional Controls}

Police use of lethal force may also be influenced by structural conditions within the city. Social disorganization theorists suggest that disadvantaged and disorganized 
communities tend to be over-policed because such conditions may contribute to higher rates of interpersonal violence and public disorder (Krivo \& Peterson 1996; Sampson \& Laub 1993). As such, residents of these communities are more likely to be the object of formal police actions like stops, searches, and arrests as well as coercive methods of policing including the use of lethal force (Klinger 1997; Sampson 1986). As a result, socioeconomic indicators of community characteristics such as the level of poverty may contribute to disorderly behavior that may influence the amount of violence police use in the jurisdictions (for elaboration see Jacobs \& O'Brien 1998). Thus, to the extent that economic disadvantage in a community may influence levels of police coercion, this source of disorder should be accounted for in any properly specified analysis.

Similarly, scholars have argued that the presence of a large, unsupervised adolescent population within a community may produce disorderly acts that require police intervention, including the use of force (Wortley \& Tanner 2003; Cohen \& Felson 1979). A number of proxies have been used to gauge low levels of youth supervision within a community including high rates of family disruption (Sampson \& Laub 1993). The size of the unsupervised youth population has also been measured by the extent of young male joblessness (Krivo \& Peterson 1996). Because related research in the U.S. has shown that these community indicators of the unsupervised youth population help explain police killings (Jacobs \& O'Brien 1998), we control for these measures in our analysis.

We also consider the overall size of the police force and the population of each city. The size of the city is included as a control variable since urban theorists have long argued (Wirth 1938) that large cities experience a breakdown of informal social control mechanisms and an increase in anonymity. Both conditions make policing more difficult in larger urban areas and may lead to higher levels of formal police actions including the use of force (Sampson \& Groves 1989). Finally, because police contacts with citizens are greater in cities with more police officers, it seems plausible that such increases will result in more police intervention including the use of force. To account for these possibilities, all of our models include both of these controls.

\section{Data and Measures}

The Sample and Dependent Variable

In order to test these hypotheses, we use a three panel dataset for the years 1999, 2000, and 2006 that includes information for all Canadian cities whose population was greater than 100.000 in 2000. Our analyses begin with 1996 data as this is the first Canadian Census that included the visible minority variable. We stop in 2006 because this is the last Census where the variable was captured. Statistics Canada dropped the long-form from the Census beginning in the 2011 Census and, as such, no longer included questions about ethnic origin that could be used to calculate a visible minority population. Panel data is advantageous compared to time-series or cross-sectional data because it overcomes problems with heterogeneity due to unmeasured explanatory variables in cross-sections, which can cause bias in estimation (Kennedy 2003). In addition, it provides the most efficient estimation possible since one can combine both 
cross-sectional and over time variation, thereby creating more variability and alleviating potential multicollinearity problems. Finally, using panel data separated by multiple years in a pooled time-series design substantially reduces serial correlation and the effects of measurement error (Johnston \& DiNardo, 1997). Due to missing values and other statistical transformations, the total number of cases (city-panels) for the analyses of total police killings is 117 city-years (39 cities over three panels).

The dependent variable for this study is the total number of police shooting deaths in each city in our sample. As discussed above, research on police violence in Canada has been heavily constrained by the lack of available data. Police officials are not compelled to release official statistics on police killings or any other use of force (for elaboration see Wortley 1999). To overcome this limitation we follow Pedicelli (1998) by using publically available news accounts taken from ProQuest's Canadian Newsstand dataset to capture police shootings. This online archive allows for full text keyword searches of nearly 300 newspapers across Canada. We conducted a detailed search of these news sources using a set of keywords that allowed us to capture the police shooting deaths that took place across Canada annually between 1996 and $2010^{1}$ (see Endnote 1 for the keyword search sting used). Data collection for each of these years required extensive coding as thousands of 'hits' were produced per year with most being false positives (the keywords used returned virtually every homicide or death of any kind - including the shooting deaths of animals - that police responded to each year across Canada). Research assistants read each entry and identified news accounts of police who shot suspects to death.

Our study focuses on police shooting deaths rather than all types of deaths associated with police action for a number of reasons but principally because we are most interested in examining cases where there is clear intent to kill citizens. In their training, officers are taught to use their firearm in situations where inflicting lethal force is required to protect their own life or that of another (Alpert \& Dunham 2004). It is difficult to gauge whether or not officers intend to kill in other incidents that lead to death due to their actions (e.g. during police chases, suspect death after the use of nonlethal assets such as a Taser, or death after an aggressive arrest). Even if one could make credible determinations of such intent, the news sources we used to collect the relevant police killings data in Canada cannot be relied upon to capture all of these instances. To avoid such error we limit our study to the most conservative measure of lethal actions used by officers-police shooting deaths.

When constructing our dependent variable, we follow prior scholarship in the area by using a 1-year lag between all of the explanatory variables and the outcome to ensure the appropriate causal order (Carmichael \& Kent 2014). Thus, explanatory variables in 1996 will be used to predict police killings in the following year(s). Also, because police killings are a rather rare event, we sum the total number of police shooting deaths in the 4 years after each panel (i.e. the sum of police shootings within a given city in 1997, 98, 99, and 2000, and so on). Employing this technique decreases the possibility that idiosyncratic events will distort the results (see Jacobs \& Carmichael 2002 for precedent on summing counts of rare events). 
Data for the explanatory variables was taken largely from the Canadian Censuses in 1996, 2001 and 2006. We measure racial and ethnic threat using three separate measures: 1) the percentage of visible minorities in each city; 2) the percentage Aboriginal; and 3) the percentage immigrant. Given the sizable overlap in the visible minority population and the immigrant population (roughly $70 \%$ of immigrants are visible minorities) the two variables are highly collinear. To isolate the independent influence of each of these factors without the influence of collinearity, we model each of these two variables separately. Social disorganization theory is also modeled using three separate indicators. Following other research on policing (e.g. Kent \& Jacobs 2005), we operationalize family instability using the percentage divorced in each city. We gauge young male joblessness using the rate of unemployment for males ages 15 to 24 . Finally, we measure the rate of poverty with using the percent of the city population below the Low Income Cut-off (LICO) as reported by the Statistics Canada. LICO represents an income threshold below which an individual would have difficulty affording basic necessities (food, clothing and housing). Data for all of the threat variables, those accounting for social disorganization, as well as population figures were taken from publically available Canadian Census data.

Figures on the percentage of female police officers and the rate of police officers per 100.000 residents in each city were taken from the Canadian Centre for Justice Statistic's Police Resources in Canada (1996, 2001, and 2006). Finally, we follow other scholarship in the relevant literature (e.g. Kent \& Jacobs 2005) and gauge violent crime using the homicide rate in each city. Homicide data is taken from the Incidentbased crime statistics produced by the Bureau of Justice Statists unit of Statistics Canada. The homicide figures include first and second degree murders as well as manslaughter.

\section{Estimation}

Relationships are estimated using negative binomial regression because this technique is the most appropriate for count dependent variables and is superior to Ordinary Least Squares regression. OLS assumes a normal distribution but because there are no or few police killings in most cities, the distribution of police killings is heavily skewed. But the biggest problem with OLS is that it produces biased and inconsistent estimates when the dependent variable contains many zero values which is often the case in count models (Long 1997). Using negative binomial regression instead should produce more accurate results than those from studies that use OLS to analyze rates of rare events. Another reason this technique is most appropriate for modeling rare events is because it treats the outcome as a raw count rather than using a rate. Rates are problematic when accounting for rare events that affect a small population at risk (for elaboration see Osgood 2000). Both Poisson regression and its' variant, negative binomial regression, are suitable specifications for analyses of raw counts, but negative binomial is a better fit when over-dispersion (variances greater than the means) is present, as is the case in our data. Finally, because these analyses use data for the same sample of units over several time periods it is possible that the number of police killings in one time period is affected by the number of killings in the previous period. To eliminate serial correlation 
a version of random effects called population averaged modeling is employed. We also examined the variance inflation factor and found that no score was above 4 suggests that our results will not be overly degraded by the presence of multicollinearity (Greene 2012). ${ }^{2}$

\section{Results}

\section{Descriptive Statistics}

Table 1 provides a summary of the expected directions of relationships between the explanatory variables and our dependent variable along with the means for all explanatory variables in each of our three panels as well as the overall standard deviation. Positive relationships are expected between most explanatory variables and the dependent variable. Only female representation on the police force should have a negative effect on police killings.

An examination of the data suggests that, much like the U.S. and other Western countries, police killings in Canada are a very rare event with an average of just under one police killing in each city during each panel. The data suggest that the number of police shooting deaths has remained relatively constant during the period we consider (1996-2010), but we also see that sufficient variation exists between cities to conduct our analysis, with the range of police killings as low as zero in some cities and as high as nine (Toronto) in others. Two other descriptive statistics are also noteworthy. First, we see that departments vary widely in the degree to which they employ female officers from a low of less than $3 \%$ to as high as $30 \%$ of the city police force. Such variation should allow for a robust test of the hypothesis that female officers should reduce violent police action.

Table 1 also identifies substantial variation in the size of the minority population such that some cities have less than $1 \%$ while visible minorities and immigrants account for the demographic majority in other cities. Clearly, the three main ethnic groups in Canada are geographically concentrated into particular cities and nearly absent from others. Importantly, these groups are not only geographically concentrated but our data also identifies the rather substantial growth in the ethnic minority population in many of these cities. Our data shows, for instance, that neither the visible minority population nor the immigrant population reached a demographic majority in any city in Canada in 1996 (the highest were $49 \%$ and $48 \%$, respectively) but by 2006 the visible minority population accounted for as much as $65 \%$ of the total population in the city and immigrants reached as high as $57 \%$ of the population (both in Richmond, BC). Our multivariate results will allow us to see if such variation in the minority population produces the kind of coercive reaction by police suggested by ethnic threat theories.

\footnotetext{
${ }^{2}$ VIF scores were based on our base model without interactions which produce high levels of unavoidable multicolinearity. Also, the scores were from a model that did not include the presence of immigrants. As mentioned in the text, the percentage immigrant and percentage visible minority are bighly correlated. We account for this by testing each in separate models, thereby removing the threat of collinearity.
} 
Table 1 Predicted signs and descriptive statistics

\begin{tabular}{|c|c|c|c|c|c|c|c|}
\hline Variable & $\begin{array}{l}\text { Predicted } \\
\text { Sign }\end{array}$ & $\begin{array}{l}\text { Mean } \\
1996\end{array}$ & $\begin{array}{l}\text { Mean } \\
2001\end{array}$ & $\begin{array}{l}\text { Mean } \\
2006\end{array}$ & $\begin{array}{l}\text { St. Dev. } \\
\text { (Overall) }\end{array}$ & $\begin{array}{l}\text { Min } \\
\text { (Overall) }\end{array}$ & $\begin{array}{l}\text { Max } \\
\text { (Overall) }\end{array}$ \\
\hline \# of Police shootings & & 0.68 & 0.77 & 0.73 & 1.38 & 0 & 9 \\
\hline Police per 100.000 & + & 148.70 & 143.25 & 151.80 & 33.79 & 86.06 & 254.73 \\
\hline $\begin{array}{l}\text { Homicides Rate per } \\
100.000\end{array}$ & + & 1.75 & 1.41 & 1.87 & 1.25 & 0 & 5.43 \\
\hline Population & + & 393.104 & 434.940 & 444.122 & 483.320 & 47036 & 2.607 .637 \\
\hline $\begin{array}{l}\% \text { Female police } \\
\text { officers }\end{array}$ & - & 11.53 & 15.37 & 17.99 & 5.33 & 2.91 & 30 \\
\hline$\%$ Visible minority & + & 13.48 & 15.66 & 18.04 & 15.21 & 0.51 & 64.75 \\
\hline$\%$ Immigrant & + & 19.72 & 20.26 & 20.86 & 14.08 & 0.95 & 57.13 \\
\hline$\%$ Aboriginal & + & 1.63 & 1.97 & 2.29 & 2.38 & 0.07 & 10.06 \\
\hline $\begin{array}{l}\text { Young male } \\
\text { unemployment }\end{array}$ & + & 17.85 & 14.14 & 14.09 & 3.90 & 8.1 & 28.6 \\
\hline$\%$ Poverty (LICO) & + & 21.25 & 17.51 & 16.61 & 5.96 & 7.1 & 34.8 \\
\hline$\%$ Divorced & + & 7.70 & 7.86 & 8.12 & 1.84 & 4.04 & 13.09 \\
\hline
\end{tabular}

\section{Negative Binomial Regression Results}

Table 2 presents the results from our pooled time-series negative binomial regression analyses of police killings in Canadian cities. As previously mentioned, the presence of visible minorities in a city is highly correlated with that of immigrants. To avoid the possibility of our results being degraded by multicollinearity we alternate testing these two variables in Model 1 and Model 2. Models 3 through 5 refine our base specification by separately testing the possibility of a non-linear relationship between three of the variables in our analyses and police killings by entering a squared term for each. Our last Model tests the possibility that a joint effect exists between female officers and the presence of visible minorities.

Findings from all of our Models show that, despite conventional expectations, the homicide rate does not have a statistically significant influence on the number of police killings. Our results are, however, consistent with expectations derived from urban theories. There is a positive and significant relationship between the population of a city and the number of police shootings in each of our five Models. As discussed above, urban scholars attribute such a relationship to the breakdown in informal controls and an increase in anonymity in large cities such that more coercive police action is necessary to maintain control (Sampson \& Groves 1989). Variables used to assess the possibility that a large, unsupervised adolescent population within a city may increase the possibility of police use of lethal force receive rather mixed support. The presence of a large unemployed male youth population does not appear to produce more violent tactics by police officers but higher rates of family disruption are positively associated with police killings in three of our five models. Additionally, contrary to our initial expectations, three of our Models show that cities with higher rates of poverty have fewer police killings with two Models indicating that this relationship is not statistically significant. 
Table 2 Negative binomial estimates of the number of police shooting deaths in Canadian Cities, 1996-2006

\begin{tabular}{|c|c|c|c|c|c|c|}
\hline & Model 1 & Model 2 & Model 3 & Model 4 & Model 5 & Model 6 \\
\hline \multicolumn{7}{|l|}{ Control variables } \\
\hline Police per 100.000 & $\begin{array}{l}0.007 \\
\quad(0.005)\end{array}$ & $\begin{array}{l}0.007 \\
\quad(0.005)\end{array}$ & $\begin{array}{l}0.007 \\
\quad(0.005)\end{array}$ & $\begin{array}{l}0.006 \\
\quad(0.006)\end{array}$ & $\begin{array}{l}0.004 \\
\quad(0.006)\end{array}$ & $\begin{array}{l}0.006 \\
\quad(0.005)\end{array}$ \\
\hline $\begin{array}{l}\text { Homicides Rate per } \\
100.000\end{array}$ & $\begin{array}{l}0.018 \\
\quad(0.076)\end{array}$ & $\begin{array}{r}-0.007 \\
(0.074)\end{array}$ & $\begin{array}{l}0.014 \\
\quad(0.073)\end{array}$ & $\begin{array}{l}-0.026 \\
\quad(0.081)\end{array}$ & $\begin{array}{l}-0.003 \\
\quad(0.089)\end{array}$ & $\begin{array}{l}0.004 \\
\quad(0.078)\end{array}$ \\
\hline Population ${ }^{\mathrm{a}}$ & $\begin{array}{l}0.011 * * \\
(0.004)\end{array}$ & $\begin{array}{r}0.013 * * * \\
(0.004)\end{array}$ & $\begin{array}{r}0.013 * * * \\
(0.004)\end{array}$ & $\begin{array}{l}0.010^{* *} \\
(0.003)\end{array}$ & $\begin{array}{l}0.011^{* *} \\
\quad(0.004)\end{array}$ & $\begin{array}{r}0.011^{* * * *} \\
(0.003)\end{array}$ \\
\hline \multicolumn{7}{|l|}{ Female police officers } \\
\hline $\begin{array}{l}\% \text { Female Police } \\
\text { Officers }\end{array}$ & $\begin{array}{r}-0.061^{*} \\
(0.028)\end{array}$ & $\begin{array}{r}-0.058^{*} \\
(0.028)\end{array}$ & $\begin{array}{l}0.113 \\
\quad(0.111)\end{array}$ & $\begin{array}{r}-0.056^{*} \\
(0.026)\end{array}$ & $\begin{array}{r}-0.066^{* *} \\
(0.026)\end{array}$ & $\begin{array}{l}0.033 \\
\quad(0.044)\end{array}$ \\
\hline $\begin{array}{l}\% \text { Female Police } \\
\text { Officer Squared }\end{array}$ & - & - & $\begin{array}{r}-0.005^{+} \\
(0.003)\end{array}$ & - & - & - \\
\hline \multicolumn{7}{|l|}{ Minority threat variables } \\
\hline$\%$ Visible Minority & - & $\begin{array}{l}0.046^{*} \\
\quad(0.020)\end{array}$ & $\begin{array}{l}0.040^{*} \\
\quad(0.019)\end{array}$ & $\begin{array}{r}0.170^{* * *} \\
(0.044)\end{array}$ & - & $\begin{array}{l}0.110^{* * * *} \\
(0.022)\end{array}$ \\
\hline $\begin{array}{l}\% \text { Visible Minority } \\
\text { Squared }\end{array}$ & - & - & - & $\begin{array}{r}-0.002^{* * * *} \\
(0.001)\end{array}$ & - & - \\
\hline$\%$ Immigrant & $\begin{array}{l}0.075^{* *} \\
(0.024)\end{array}$ & - & - & - & $\begin{array}{r}0.223 * * * \\
(0.053)\end{array}$ & - \\
\hline $\begin{array}{l}\% \text { Immigrant } \\
\text { Squared }\end{array}$ & - & - & - & - & $\begin{array}{r}-0.002 * * \\
(0.001)\end{array}$ & - \\
\hline$\%$ Aboriginal & $\begin{array}{l}0.200^{* *} \\
(0.069)\end{array}$ & $\begin{array}{l}0.143^{*} \\
\quad(0.065)\end{array}$ & $\begin{array}{l}0.128^{*} \\
\quad(0.064)\end{array}$ & $\begin{array}{l}0.177^{*} \\
\quad(0.070)\end{array}$ & $\begin{array}{r}0.268 * * * \\
(0.072)\end{array}$ & $\begin{array}{l}0.133^{*} \\
\quad(0.066)\end{array}$ \\
\hline \multicolumn{7}{|l|}{ Social disorganization } \\
\hline $\begin{array}{l}\text { Young Male } \\
\text { Unemployment } \\
\text { Rate }\end{array}$ & $\begin{array}{l}-0.011 \\
\quad(0.056)\end{array}$ & $\begin{array}{r}-0.028 \\
(0.056)\end{array}$ & $\begin{array}{r}-0.036 \\
(0.057)\end{array}$ & $\begin{array}{l}0.027 \\
\quad(0.059)\end{array}$ & $\begin{array}{l}0.033 \\
\quad(0.057)\end{array}$ & $\begin{array}{r}-0.040 \\
\quad(0.059)\end{array}$ \\
\hline$\%$ Poverty (LICO) & $\begin{array}{r}-0.069^{*} \\
(0.038)\end{array}$ & $\begin{array}{r}-0.047 \\
\quad(0.038)\end{array}$ & $\begin{array}{r}-0.026 \\
\quad(0.039)\end{array}$ & $\begin{array}{r}-0.058^{+} \\
(0.034)\end{array}$ & $\begin{array}{r}-0.077^{*} \\
(0.036)\end{array}$ & $\begin{array}{r}-0.019 \\
\quad(0.038)\end{array}$ \\
\hline$\%$ Divorced & $\begin{array}{l}0.341^{*} \\
(0.161)\end{array}$ & $\begin{array}{l}0.161 \\
\quad(0.149)\end{array}$ & $\begin{array}{l}0.124 \\
\quad(0.146)\end{array}$ & $\begin{array}{l}0.254^{+} \\
\quad(0.154)\end{array}$ & $\begin{array}{l}0.474 * * \\
(0.161)\end{array}$ & $\begin{array}{l}0.123 \\
\quad(0.139)\end{array}$ \\
\hline \multicolumn{7}{|l|}{ Interaction terms } \\
\hline $\begin{array}{l}\% \text { Female Officer X \% } \\
\text { Visible Minority }\end{array}$ & - & - & - & - & - & $\begin{array}{c}-0.004 * * * \\
(0.001)\end{array}$ \\
\hline Constant & -4.844 & -2.753 & -3.766 & -4.986 & -7.724 & -3.713 \\
\hline \# of City-Years & 117 & 117 & 117 & 117 & 117 & 117 \\
\hline Adj. $\mathrm{R}^{2}$ & 0.774 & 0.772 & 0.770 & 0.778 & 0.774 & 0.776 \\
\hline
\end{tabular}

Two-tailed tests on all coefficients. Robust (clustering on city) Standard Errors are in parentheses. All models corrected for unspecified heteroskedasticity using White's (1981) correction

${ }^{a}$ Coefficients and SE multiplied by 10.000

${ }^{+} P \leq 0.1$

$* P \leq 0.05$

$* * P \leq 0.01$

*** $P \leq 0.001$ 
Models 1 and 2 also examine the linear relationship between the percentage of female officers in the city police force and the use of lethal force. Consistent with prior scholarship on the use of lethal force by policewomen (Alpert \& Dunham 2004; Hoffmann \& Hickey 2005), we find that cities with more female officers have significantly fewer police killings than jurisdictions with few women officers. This provides rather convincing evidence that policymakers and police administrators are moving in the right direction by hiring more female officers as such changes appear to be reducing the use of lethal force. In Model 3 we will attempt to assess in more detail the possibility, advanced by Skolnick and Fyfe (1993), that female officers influence violent police actions, not only because they are less likely to use force but because they may change the entire sub-culture on the police force.

Our first two Models also assess threat explanations with the presence of Aboriginals and alternate tests of the influence of immigrants (Model 1) and visible minority populations (Model 2). Results show that cities with more visible minorities, immigrants, and/or Aboriginal peoples have more police killings. This is consistent with threat expectations which suggest that such a relationship exists because majority group members are threatened by minorities and will use their disproportionate influence over the law and law enforcement to coerce and control groups who are viewed as threatening to the social order and the status quo that benefits the dominant group (Turk 1969; Quinney 1977; Collins 1975). Models 4 and 5 will assess the possibility that these relationships may be non-linear.

Our first two Models use a linear specification of policewomen on the force and the coefficients are statistically significance in each of the Models such that fewer lethal police actions occur in jurisdictions with more female officers. Such a linear specification, though, may simply be reflecting individual female officers' disinclination to use lethal force. To test Skolnick and Fyfe's (1993) assertion that the presence of female officers on the force can change the culture of entire police departments by making all officers less likely to use violent tactics, Model 3 introduces a squared term for the presence of female officers in a jurisdiction to allow the variable to take on a non-linear form. We assume, here, that a cultural shift within a police department could be attributable to more female officers within a department if the relationship between the female presence and police killings declined exponentially. Results from Model 3 are at least suggestive that more female officers are producing changes to the police subculture within their department. In particular, we find indications of a threshold effect operating between this variable and our outcome such that at lower levels of female participation in the police force there is no significant relationship (i.e. a nonsignificant main effect) but once women reach a threshold we see an exponential decline in lethal police action. ${ }^{3}$ We calculate the precise point at which this threshold takes place and find that once women reach about $11 \%$ of the force the exponential reduction of police killings begins. While this non-linear effect is only significant at the 0.1 alpha level, it is at least suggestive of the idea that women are not simply decreasing the use of lethal force because they are less likely to employ such tactics but that they may be changing the culture of these departments in ways that make even the male officers on the force less violent.

\footnotetext{
${ }^{3}$ The negative sign on the squared terms suggests that the relationship is best described as an inverted Ushaped curve.
} 
Model 4 and 5 assess the possibility that the relationship between minority presence and lethal police action may be non-linear because once these groups comprise a sizable proportion of the population they may be able to mobilize to pressure politicians to adopt policies that make the use of lethal force less likely (see Jackson 1989; Turk 1969). Our results provide rather strong support for this expectation with both the presence of immigrants and visible minorities having a significant non-linear relationship in the shape of an inverted U. Consistent with both Jackson (1989) and Horowitz (1985) police killings rise along with minority presence but once they reach a threshold they began to level off and then decline. Our calculation of the inflection point suggests that once visible minorities and immigrants approach a numerical majority within a city ( $41.4 \%$ and $48.2 \%$ respectively) lethal police action begins to decline. ${ }^{4}$ Overall, it appears that the presence of ethnic minorities increases majority group fears about these groups and such fears result in devastating consequences in the form of lethal police action.

Our final Model assesses the possibility that female representation on the police force and the size of the visible minority population affect the outcome jointly rather than independently. While our earlier tests of the influence of female officers on police killings identified a direct effect such that more policewomen patrolling the streets reduced lethal police action, it seems at least plausible that policewomen in jurisdictions with a large minority presence may be less likely to affect deadly force incidents. Drawing from conflict theories of police action, it is plausible that police administrators in the most ethnically diverse cities may be either less inclined to hire large numbers of female officers or, if they do, policewomen in these jurisdictions may be less able to change the aggressive subculture prevalent in policing. If this line of reasoning is accurate, we would expect to find no relationship between female representation on the police force in cities with a sizable minority population. To test the possibility of such a joint effect, Model 6 introduces an interaction term between the percentage female officers and the presence of visible minorities. Results run contrary to our expectations. We find that even when female officers are employed in the most ethnically diverse cities there is a reduction in lethal police action. This finding, together with those from previous Models, offer robust support for Skolnick and Fyfe's (1993) assertions that hiring more female officers can reduce violent police behavior.

\section{Additional Considerations}

Beyond what we report in Table 2, we also analyzed a variety of alternative specifications of our models to assess the robustness our findings (results not shown but available from the authors upon request). First, we considered alternative specifications of minority compositions. In particular, we tested a measure of overall ethnic make-up of each city (i.e. the sum of $\%$ visible minority, \% Immigrant, and \% Aboriginal). This combined measure was positively related to police strength. We opted for separate measures, though, as separate measures more accurately accounts for the unique relationship between each separate group and police strength. As our primary results show, each particular ethnic group has a specific influence on the size of metropolitan

\footnotetext{
${ }^{4}$ We do not include a non-linear test of the presence of Aboriginal peoples because they do not make-up a large enough proportion of any city to trigger the type of threshold effect discussed.
} 
police departments and a combined measure would mask this effect. We also tested an alternative account of crime by assessing the influence of the overall crime rate and the violent crime rate on police killings. Results were consistent with those presented for homicide rates and indicated that neither of these alternative measures of crime achieved the level of statistical significance when introduced into our base model. Finally, we introduced a series of dummy variables for each province in Canada to see if idiosyncrasies in each may be producing meaningful differences in police killings and found that these dummies did not reach the level of statistical significance and did not influence our overall results. Taken together, our findings appear to be robust to changes in specification.

\section{Conclusion}

This threshold finding is consistent with expectations derived from Critical Mass Theory which suggests that when women account for only a small fraction of a male-dominated occupation they are highly marginalized and unlikely to change institutional culture but once they move beyond 'token' representation they can affect change in policy and practice (see Kanter 1977; Bratton 2005; Grey 2002). In her seminal work on this topic, Kanter (1977) claimed that the numerically 'dominant' group within occupations with a highly skewed sex ratio "control the group and its culture' while the numerically few must conform to dominant norms or risk isolation and/or stigmatization (p.966). Scholars have often pointed to a threshold or "critical mass" that allows women or other minorities within an institution to escape a simple token representation. Most have found that this critical mass is reached once women represent roughly $15 \%$ of an occupation or institution (Belknap and Shelley 1992). Above this threshold women are no longer simply token members and, as such, tend to be much less marginalized and begin to have some influence over institutional culture. Evidence of this $15 \%$ threshold has been identified in a variety of settings including female representation in state legislatures (Bratton 2005; Grey 2002; Wolbrecht 2000), in the U.S. Congress Swers (2002)), the corporate executive ranks (Kanter 1993), and on corporate boards (Nielsen and Huse 2010). The policing literature claims that tokenism reduces female police officers' inclination to pursue promotion (Wertsch 1998; Archbold \& Schulz 2008), and results in reduced levels of job satisfaction (Hassell, Archbold, \& Stichman 2011). Findings from our study suggest that a similar threshold operates within policing such that once women break-out of a simple token representation within a department (our results suggest this happens once policewomen account for roughly $11 \%$ or more of the force) there are fewer police killings in that jurisdiction.

Another concern of this study was to test the applicability of ethnic threat theories in the Canadian context. These accounts argue that relations between police and citizens are simply a reflection of the racial and ethnic divisions within the broader society (e.g. Blalock 1967). Furthermore, threat theorists suggest that law enforcement, and criminal law itself, favors dominant group members and targets minority communities for aggressive policing strategies because these groups are considered violent and criminogenic and a threat to the overall social order (Gordon 2006; Jacobs and Carmichael 2001). While this theoretical account has received substantial attention 
and empirical support within the U.S., few have attempted to test the applicability of such claims in the Canadian context. With some modifications to the typical BlackWhite dichotomy employed to test threat expectations in the U.S., we find that the size of the ethnic minority population in Canadian cities does indeed influence the incidence of police killings. Specifically, we find robust and consistent evidence linking the presence of immigrants, visible minorities and Aboriginal peoples to more lethal assaults by police officers. It appears then, that despite the rather sharp historical and contextual differences that exist between the U.S. and Canada and despite the apparent embrace of multiculturalism in Canada, ethnic divisions are, consistent with threat expectations, influencing coercive mechanisms of the state that appear to target minority communities.

There is, however, some evidence in our results that suggests minorities may be able to reverse this association in specific contexts. When we assess non-linear specifications for the presence of visible minorities and immigrants we find that once minorities approach a numerical majority in a city there is a leveling-off and then a decline in police killings. This is consistent with political expectations advanced by both Horowitz (1985) and Jackson (1989) who argue that such numerical gains can increase the political clout of minorities and force political elites to modify polices policies that aggressively target members of minority populations. Such policy modifications may include changes that make the use of lethal force by officers less likely.

We also took several other theoretical considerations into account. We found no support for reactive theories which suggest that lethal police action is a response to the level of violence (homicide rates) in a given jurisdiction. Only mixed support was offered for the influence of social disorganization on the incidence of police killings. In particular, some of our Models offered support for the idea that the presence of a large, unsupervised adolescent population within a community may increase the use of force perhaps because these youth are more likely to engage in criminal activity requiring police intervention including the increased use of force (see Wortley \& Tanner 2003; Cohen \& Felson 1979). Overall, our most specified models account for over $77 \%$ of the variation in police killings across our sample of Canadian cities. This suggests that the theoretically derived factors we assess here are capturing the vast majority of the important contributors influencing variation in the use of lethal force by Canadian police officers.

Together, our results vastly improve our understanding of variations in the use of lethal force by Canadian police officers. The findings offer robust evidence that the conflict perspective of the legal order is relevant in the Canadian context. The significant association between the presence of ethnic minorities and incidence of lethal police action at least suggests that police may be more willing to employ deadly tactics to regulate members of minority communities. Given this relationship, there may be cause for concern regarding Canadian ethnic relations. The threat posed by the presence of minorities in Canadian cities appears to have potentially deadly consequences for people of color. That said, our results offer at least some hope that this situation can be mitigated by some contextual factors. This study offers strong support that policymakers and police administrators who wish to reduce the risk of lethal police action should more aggressively pursue efforts to hire additional female officers. Finally, there appears to be political strength in numbers for ethnic minorities in Canada. Our results offer compelling evidence that as these groups reach a numerical 
majority (as they do in several cities already) they appear to be able to mobilize in ways that make violent police action less likely.

Acknowledgments Early drafts of this research were presented at the Canadian Sociological Association annual meeting (2013) in Victoria, BC.

Funding This work was supported by a grant from the Fonds de Recherche sur la Société et la Culture, Québec (FQRSC).

\section{References}

Adam, K. (2004). What we know about police use of force. In Q. C. Thurman \& J. Zhao (Eds.), Contemporary policing: controversies, challenges, and solutions (pp. 187-199). Los Angeles: Roxbury. Alpert, G. P., \& Dunham, R. G. (2004). Understanding police use of force: Officers, suspects, and reciprocity. New York: Cambridge University Press.

Archbold, C. A., \& Schulz, D. M. (2008). Making rank: the lingering effects of tokenism on female police officers' promotion aspirations. Police Quarterly, 11, 50-73.

Belknap, J. (1996). The invisible woman: Gender, crime and justice. Bellmont, CA.: Wadsworth.

Belknap, J., \& Shelley, J. K. (1992). The new lone ranger: policewomen on patrol. American Journal of Police, 12, 47-76.

Binder, A., \& Fridell L. (1984). Lethal force as a police response. Criminal Justice Abstracts (June) $250-80$.

Bittner, E. (1990). Aspects of police work. Chicago: Northeastern University Press.

Black, D. (1976). The behavior of law. New York: Academic.

Blalock, H. (1967). Towards a theory of minority group relations. New York: Capricorn.

Blau, J. \& Blau, P. R. (1982). The cost of inequality: Metropolitan structure and violent crime. Am Sociol Rev, $47,114-129$

Blumberg, M. (1993). Controlling police use of force: Assessing two decades of progress. In R. Dunham \& G. Alpert (Eds.), Critical issues in policing: Contemporary readings (2nd ed., pp. 469-92). Prospect Heights: Waveland Press.

Blumer, H. (1958). Race prejudice as a sense of group position. Pacific Sociological Review, 23, 3-7.

Bratton, K. A. (2005). Critical mass theory revisited: The behavior and success of token women in state legislatures. Politics \& Gender, 1, 97-125.

Carmichael, J. T. (2005). "The determinants of jail admission rates across large U.S. cities: An analysis of racial and ethic threat theory." Social Science Research, 34, 538-569.

Carmichael, J. T. (2010). "Sentencing disparities for juvenile offenders sentenced to adult prisons: An individual and contextual analysis." Joumal of Criminal Justice: An International Journal, 38(4), 747-757.

Carmichael, J. T., \& Burgos, G. (2012). "Sentencing juvenile offenders to life in prison: The political sociology of juvenile punishment." American Journal of Criminal Justice, 37, 602-629.

Carmichael, J. T., \& Kent, S. L. (2014). The persistent significance of racial and economic inequality on the size of municipal police forces in the United States, 1980-2010. Social Problems, 61, 1-24.

Chevigny, P. (1995). Edge of the knife: Police violence in the Americas. New York: The New Press.

Cohen, L. E. \& Felson, M. (1979). Social change and crime rate trends: A routine activity approach. Am Sociol Rev, pp. 588608.

Collins, R. (1975). Conflict Sociology. New York: Academic.

Dahrendorf, R. (1959). Class and conflict in inchistrial societies. Stanford: Stanford University Press.

Doemer, W. G. (1991). Police unholstering and shooting behavior under simulated field conditions. American Journal of Police, 10, 1-16.

Fitzgerald, R. T., \& Carrington, P. J. (2011). Disproportionate minority contact in Canada: Police and visible minority youth. Canadian Joumal of Criminology and Criminal Justice, 53, 449-486.

Fletcher, J. K. (1999). Disappearing acts: Gender, power; and relational practices at work. Cambridge: MIT Press.

Friedrich, R. J. (1979). Racial prejudice and police treatment of blakcks. In R. Baker \& F. A. Meyer (Eds.), Evaluating alternative law enforcment policies (pp. 159-60). Lexington, MA: Lexington-HEath.

Fyfe, J. J. (1980). Geographic correlates of police shootings: A microanalysis. J Res Crime Delinq, 17, 101113. 
Gilligan, C. (1982). In a different voice. Cambridge: Harvard University Press.

Gordon, T. (2006). Cops, crime and capitalism: The law and order agenda in Canada. Halifax: Fernwood.

Greene, W. (2012). Econometric analysis. Boston: Prentice Hall.

Grey, S. (2002). Does size matter? Critical mass and New Zealand's women MPs. Parliamentary Affairs, 55 , 19-29.

Hassell, K., Archbold, C., \& Stichman, A. (2011). Comparing the workplace experiences of male and female police officers: examining workplace problems, stress, job satisfaction, and consideration of career change. International Journal of Police Science and Management, 13, 37-53.

Hoffmann, P. B., \& Hickey, E. R. (2005). Use of force by female police officers. Journal of Criminal Justice, $33,145-151$.

Holmes, M. D. (2000). Minority threat and police brutality: Determinants of civil rights criminal complaints in U.S. municipalities. Criminology, 38, 343-368.

Horowitz, D. (1985). Ethnic groups in coflict. University of Califomia Press.

Jackson, P. I. (1989). Minority group threat, crime and policing. New York: Praeger.

Jacobs, D., \& Britt, D. (1979). Inequality and police use of deadly force: An empirical assessment of a conflict hypothesis. Social Problems, 26, 403-412.

Jacobs, D., \& Carmichael, J. T. (2001). The politics of punishment across time and space: A pooled time series analysis of imprisonment rates. Social Forces, 80, 61-89.

Jacobs, D., \& Carmichael, J. T. (2002). "The political sociology of the death penalty: A pooled time-series analysis." American Sociological Review, 67, 109-131.

Jacobs, D., \& Carmichael, J. T. (2004). Ideology, social threat, and death sentences: Capital sentencing across time and space. Social Forces, 83, 249-278.

Jacobs, D., \& Helms, R. (1999). Collective outbursts, politics, and punitive resources: Toward a political sociology of spending on social control. Social Forces, 77, 1497-1523.

Jacobs, D., \& O’Brien, R. (1998). The determinants of deadly force: a structural analysis of police violence. American Journal of Sociology, 103, 837-862.

Johnston, J., \& DiNardo, J. (1997). Econometric methods. New York: McGraw Hill.

Kanter, R. (1977). Some effects of proportion on group life: Skewed sex ratios and response to token women. American Journal of Sociology, 82, 965-990.

Kanter, R. (1993). Men and women of the corporation. New York: Basic Books.

Kappeler, V., Sluder, R., \& Alpert, G. (1994). Forces of deviance: Understanding the dark side of policing. Prospect Heights: Waveland Press.

Kennedy, P. (2003). A Guide to Econometrics. Cambridge MA: MIT Press.

Kent, S., \& Carmichael, J. T. (2014). Racial residential segregation and social control: A panel study of variations in police strength across U.S cities, 1980-2010. American Journal of Criminal Justice, 39, 228 249.

Kent, S., \& Jacobs, D. (2005). Minority threat and police strength from 1980 to 2000: A fixed effects analysis of nonlinear and interactive effects in large U.S. cities. Criminology, 43, 731-60.

Klinger, D. A. (1997). Negotiating order in patrol work: An ecological theory of police response to deviance. Criminology, 35, 277-306.

Krivo, L., \& Peterson, R. D. (1996). Extremely disadvantaged neighborhoods and urban crime. Social Forces, 75,619648 .

Lersch, K. M., \& Mieczkowski, T. (2005). Violent police behavior: Past, present, and future directions. Aggression and Violent Behavior, 10, 552-568.

Liska, A. E., \& Chamlin, M. B. (1984). "Social structure and crime control among macrosocial units." American Journal of Sociology, 90, 383-95.

Liska, A. E., \& Yu, J. (1992). Specifying and testing the threat hypothesis: Police use of deadly force. In A. E. Liska (Ed.), Social Threat and Social Control (pp. 53-68). Albany: SUNY Press.

Long, S. (1997). Regression models for categorical and limited dependent variables. Los Angeles, CA: Sage.

Lonsway, K., Wood, M., \& Spiller, K. (2002). Officer gender and excessive force. Law and Order, 50, 60-66.

Manning, P. (1980). Violence and the police role. Annals of the American Academy of Political and Social Science, 452, 134-144.

Nalla, M. K., Lynch, M. J., \& Leiber, M. J. (1997). Determinants of police growth in Phoenix, 1950-1988. Justice $Q, 14,115-142$.

Nielsen, S., \& Huse, M. (2010). The contribution of women on boards of directors: Going beyond the surface. Corporate Governance: An International Review, 18, 136-148.

Osgood, D. W. (2000). Poisson-based regression analysis of aggregate crime rates. Journal of Quantitative Criminology, 16, 21-43.

Pedicelli, G. (1998). When police kill: Police use of force in Montreal and Toronto. Montreal: Vehicule. 
Piliavin, J. A., \& Chang, H. W. (1990). Altruism: A review of recent theory and research. Anmual Review of Sociology, 16, 27-65.

Quinney, Richard. (1977). Class, state, and crime: On the theory and practice of criminal justice. New York: Lomgman.

Rabe-Hemp, C. (2008). Survival in an all-boys club: policewomen and their fight for acceptance. Policing: An International Journal of Police Strategies and Management, 31, 251-270.

Roberts, J., \& Doob, A. (1997). Race, ethnicity, and criminal justice in Canada. In M. Tonry (Ed.), Ethnicity, Crime, and Immigration: Comparative and Cross-National Perspectives (pp. 469-522). Chicago: University of Chicago Press.

Rubinstein, J. (1973). City police. New York: The Noonday Press.

Sampson, R. J. (1986). Effects of socioeconomic context on official reaction to juvenile delinquency. American Sociological Review, 51, 876-885.

Schuck, A., \& Rabe-Hemp, C. (2005). Women police: The use of force by and against female officers. Women and Criminal Justice, 16, 91-117.

Silver, A. (1967). The demand for order in civil society: A review of some themes in the history of urban crime, police and riot. In D. J. Bordua (Ed.), The Police: Six Sociological Essays (pp. 1-24). New York: Wiley.

Skolnick, J. H., \& Fyfe, J. J. (1993). Above the law: Police and the excessive use of force. New York: Free Press.

Smith, B. W., \& Holmes, M. D. (2014). Police use of excessive force in minority communities: A test of the minority threat, place, and community accountability hypotheses. Social Problems, 61, 83-104.

Sorenson, J. R., Marquart, J. W., \& Brock, D. E. (1993). Factors related to killings of felons by police officers: A test of the community violence hypotheses. Justice Quarterly, 10, 417-440.

Sourcebook of Criminal Justice Statistics. Bureau of Justice Statistics. Washington DC.

Statistics Canada. (2013). Female officers as a percentage of total police officers, Canada, 1986 to 2012. Canadian Centre for Justice Statistics. Police Administration Survey. Ottawa: Canada. Retrieved on March 31, 2014 from: http://www.statcan.gc.ca/pub/85-225-x/2012000/ct006-eng.htm

Sampson, R. J., \& Groves, W. B. (1989). Community structure and crime: Testing social-disorganization theory. Am .J Sociol, 94, 774-802.

Sampson, R. J., \& Laub, J. H. (1993). Crime in the making: Pathways and turning points through life. Cambridge, MA.: Harvard University Press. pp. 1-24, 123-178.

Swers, M. (2002). The difference women make: The policy impact of women in Congress. Chicago: University of Chicago Press.

Turk, A. T. (1969). Criminality and the legal order. Chicago: Rand McNally.

Wertsch, T. L. (1998). Walking the thin, blue line: policewomen and tokenism today. Women and Criminal Justice, 9, 23-61.

Wirth, L. (1938). Urbanism as a way of life. Am J Sociol, 44, 1-24.

Wolbrecht, C. (2000). The politics of women's rights: Parties, positions and change. Princeton: Princeton University Press.

Wortley, S. (1999). A northern taboo: Research on race, crime, and criminal justice in Canada. Canadian Journal of Criminology, 41, 261-274.

Wortley, S., \& Owusu-Bempah, A. (2011). The usual suspects: police stop and search practices in Canada. Policing \& Society, 21, 395-407.

Wortley, S., \& Tanner, J. (2003). Data, denials and controversy: The racial profiling debate in Toronto. Canadian Journal of Criminology and Criminal Justice, 45, 367-390. 